\title{
Short stature, mental retardation, and hypoparathyroidism: a new syndrome
}

\author{
R J Richardson, J M W Kirk
}

\begin{abstract}
Eight children (four boys and four girls) with extreme failure to thrive, dysmorphic features, developmental delay, hypoparathyroidism, and abnormal skeletal survey were studied. They were the products of seven consanguinous marriages, two of the patients being brothers. In the remaining six families, a further four children had affected siblings who had died in infancy. When assessed the children were aged $0.47-12.8$ years; SD scores were $<-2$ for height, weight, and head circumference in all patients. The children
\end{abstract}

Table 1 Clinical features of the syndrome. All patients had consanguinous parents and were of short stature with developmental delay and typical dysmorphic facies

\begin{tabular}{llll}
\hline $\begin{array}{l}\text { Case } \\
\text { No }\end{array}$ & Sex & $\begin{array}{l}\text { Affected } \\
\text { siblings }\end{array}$ & $\begin{array}{l}\text { Low } \\
\text { birth weight } \\
\text { (<10th centile })\end{array}$ \\
\hline 1 & Male & Yes & Yes \\
2 & Male & Yes & Yes \\
3 & Male & No & Yes \\
4 & Male & Yes & Yes \\
5 & Female & Yes & Yes \\
6 & Female & No & Not known \\
7 & Female & Yes & Yes \\
8 & Female & Yes & Yes \\
\hline
\end{tabular}
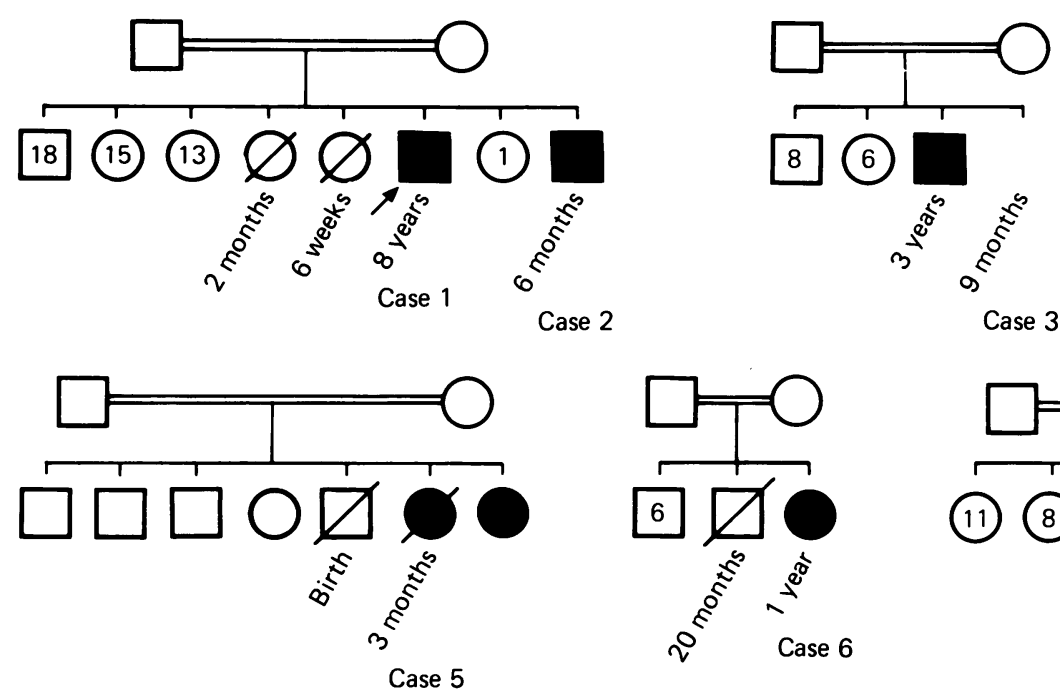

had identical facies with deep set eyes, depressed nasal bridge with beaked nose, long philtrum, thin upper lip, micrognathia, and large floppy earlobes. They were all developmentally retarded. The following abnormalities were found on investigation: hypocalcaemia in all (of whom six of seven had hypoparathyroidism), medullary stenosis and other skeletal survey defects in seven of the eight children, and reduced numbers of $T$ cell subsets in four of four tested. We believe that these children represent a new, as yet undescribed genetically determined syndrome.

During the past few years we have noted a previously undescribed pattern of congenital anomalies in eight children of Middle Eastern origin. We present these cases in the hope that early recognition may reduce morbidity and mortality from associated hypocalcaemia and sepsis, and enable further elucidation of the genetics of this syndrome.

The clinical features of the syndrome are summarised in table 1 , and show clearly the homogeneity of the abnormalities in these children. We therefore describe the index case in

Hospital for Sick Children, Great Ormond Street, London

R J Richardson

Middlesex Hospital, London

J M W Kirk

Correspondence to:

Dr J M W Kirk,

St Bartholomew's Hospital, London ECIA 7BE.

Accepted 5 April 1990
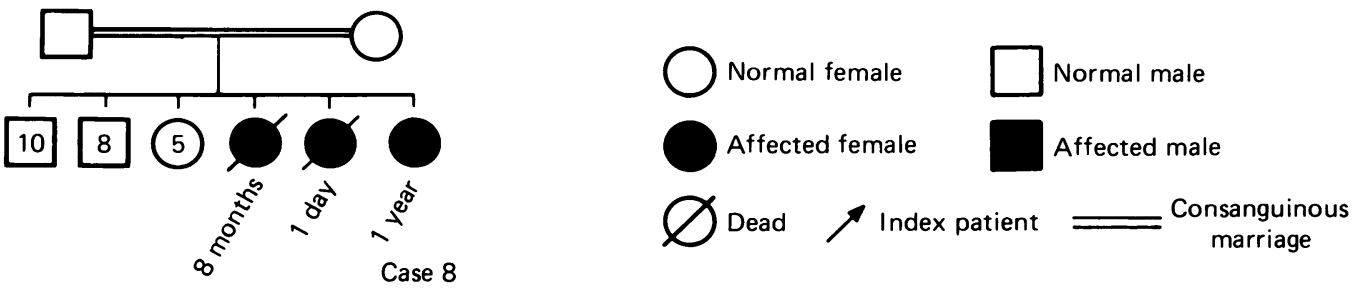
detail, and then review the abnormalities in the other patients.

\section{Case reports}

CASE 1

This infant boy was the sixth liveborn child born to consanguinous first cousins from Qatar. He was the older brother of case 2. He also had a brother aged 18 years, and two sisters aged 15 and 13 years, but two other sisters had died in infancy (fig 1).

The pregnancy was normal, although low urinary oestriol concentrations had been noted. The baby was born in the United Kingdom at full term weighing $1840 \mathrm{~g}$ (table 2). At birth he was noted to have dysmorphic featuresdeep set eyes, a beaked nose with depressed nasal bridge, long philtrum with thin upper lip, micrognathia, and large floppy earlobes (fig 2). At 3 weeks of age he developed septicaemia and streptococci, staphylococci, coliforms, and can- dida were cultured. At that time he was found to be hypocalcaemic (calcium $1.5 \mathrm{mmol} / \mathrm{l}$, reference range $2 \cdot 20-2 \cdot 67)$ with an inappropriately low parathyroid hormone concentration $(<156$ ng/l) (table 3). Treatment was started with $1 \alpha$-hydroxycholecalciferol. He was also discovered to have $\beta$ thalassaemia major, for which he required intermittent blood transfusions.

No syndrome or underlying cause was found for this child's condition, but despite treatment of both the thalassaemia and hypoparathyroidism he has remained severely developmentally and physically retarded. He started to walk at the age of 8 years and at that time speech was limited to babble and a few words, but no sentences. At the age of 12 years the vocabulary was still extremely limited, consisting only of simple phrases and sentences. Vision and hearing were normal.

Growth has been extremely poor (fig 3 ). When last reassessed at the age of $12 \cdot 8$ years his height was $81.9 \mathrm{~cm}$ with a weight of $9.0 \mathrm{~kg}$

Table 2 Auxological data

\begin{tabular}{|c|c|c|c|c|c|c|c|c|c|c|}
\hline \multirow{2}{*}{$\begin{array}{l}\text { Case } \\
\text { No }\end{array}$} & \multirow{2}{*}{$\begin{array}{l}\text { Birth } \\
\text { weight } \\
\text { (g) }\end{array}$} & \multirow{2}{*}{$\begin{array}{l}\text { Gestation } \\
\text { (weeks) }\end{array}$} & \multirow{2}{*}{$\begin{array}{l}\text { Centile } \\
(\%)\end{array}$} & \multirow{2}{*}{$\begin{array}{l}\text { Age } \\
\text { (years) }\end{array}$} & \multicolumn{2}{|c|}{ Height } & \multicolumn{2}{|c|}{ Weight } & \multicolumn{2}{|c|}{ Head circumference } \\
\hline & & & & & $\mathrm{cm}$ & $S D$ score & $k g$ & $S D$ score & $\mathrm{cm}$ & $S D$ score \\
\hline & $\begin{array}{l}1840 \\
2150 \\
2540 \\
1930 \\
2700 \\
2320 \\
\text { Not known } \\
2360\end{array}$ & $\begin{array}{l}40 \\
36 \\
37 \\
41 \\
40 \\
39 \\
\text { Not known } \\
38\end{array}$ & $\begin{array}{l}<3 \text { rd } \\
<3 \text { rd } \\
<10 \text { th } \\
<3 \text { rd } \\
<10 \text { th } \\
<3 \text { rd } \\
\text { Not known } \\
<3 \text { rd }\end{array}$ & $\begin{array}{r}12 \cdot 81 \\
5 \cdot 17 \\
3.01 \\
1.91 \\
1.47 \\
1.09 \\
0.09 \\
1 \cdot 24\end{array}$ & $\begin{array}{l}81 \cdot 9 \\
69 \cdot 1 \\
76 \cdot 2 \\
61 \cdot 2 \\
61 \cdot 5 \\
54 \cdot 5 \\
46 \cdot 5 \\
51 \cdot 4\end{array}$ & $\begin{array}{r}-10 \cdot 6 \\
-8 \cdot 4 \\
-4 \cdot 7 \\
-7 \cdot 7 \\
-6 \cdot 3 \\
-7 \cdot 6 \\
-3 \cdot 3 \\
-9 \cdot 2\end{array}$ & $\begin{array}{l}9 \cdot 0 \\
7 \cdot 0 \\
7 \cdot 2 \\
4 \cdot 5 \\
3 \cdot 7 \\
3 \cdot 5 \\
2 \cdot 4 \\
2 \cdot 9\end{array}$ & $\begin{array}{l}-3 \cdot 6 \\
-5 \cdot 3 \\
-4 \cdot 6 \\
-5 \cdot 8 \\
-6 \cdot 6 \\
-6 \cdot 2 \\
-2.9 \\
-7 \cdot 0\end{array}$ & $\begin{array}{l}45 \cdot 0 \\
40 \cdot 0 \\
42 \cdot 8 \\
39 \cdot 4 \\
40 \cdot 2 \\
38 \cdot 5 \\
33 \cdot 0 \\
38 \cdot 6\end{array}$ & $\begin{array}{l}-9 \cdot 1 \\
-8 \cdot 7 \\
-4 \cdot 0 \\
-6 \cdot 2 \\
-4 \cdot 9 \\
-5 \cdot 3 \\
-2 \cdot 3 \\
-5 \cdot 5\end{array}$ \\
\hline
\end{tabular}
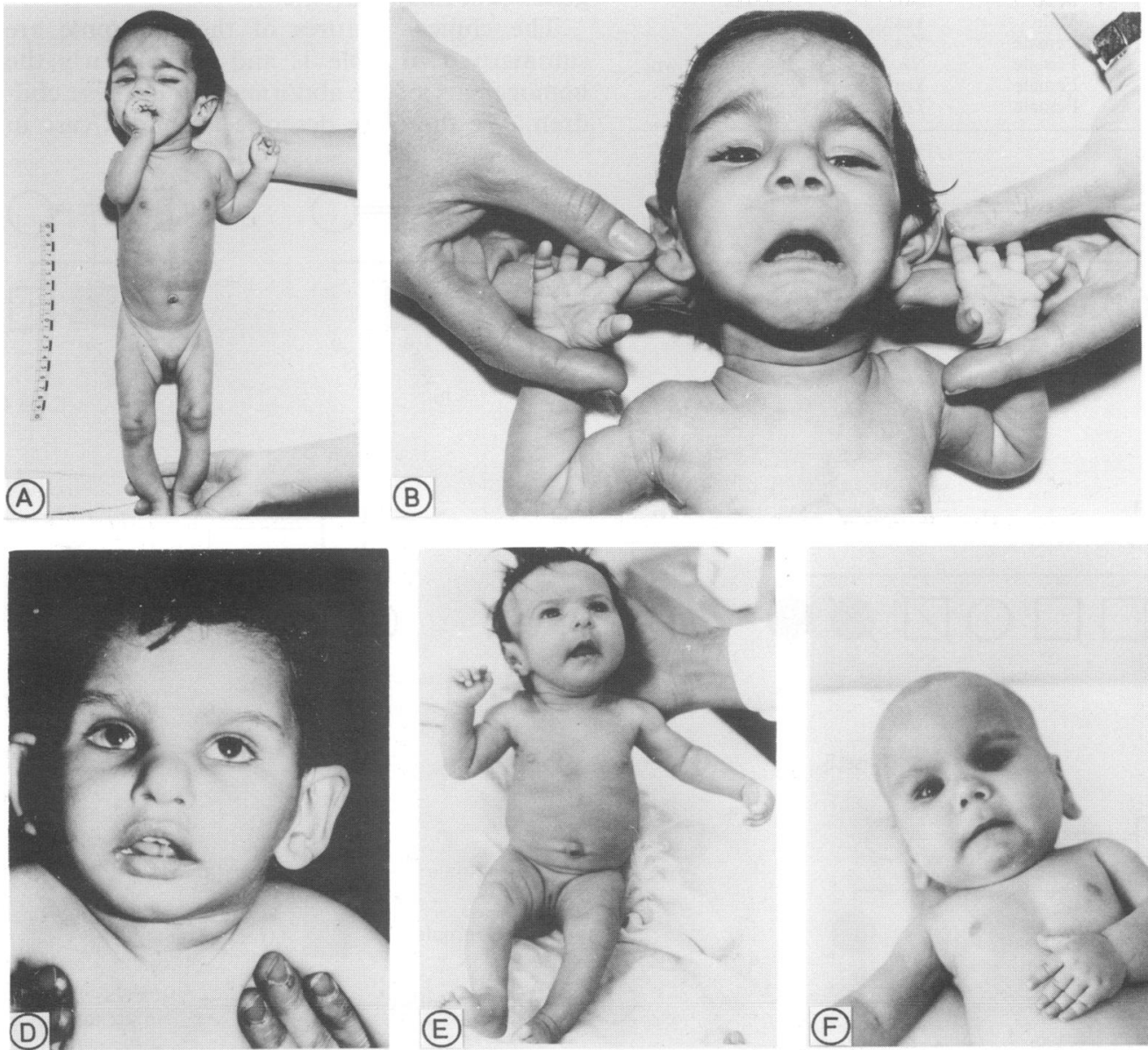

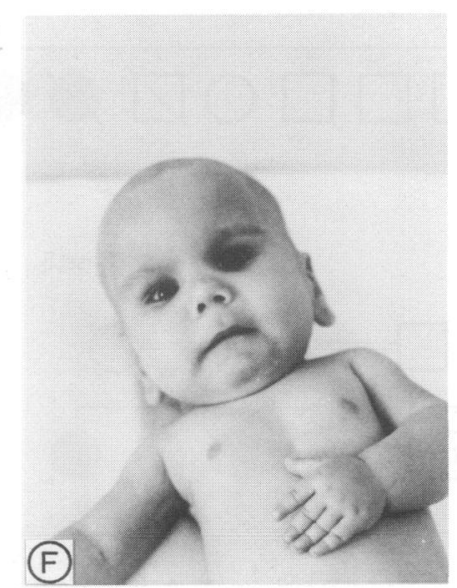

(C)
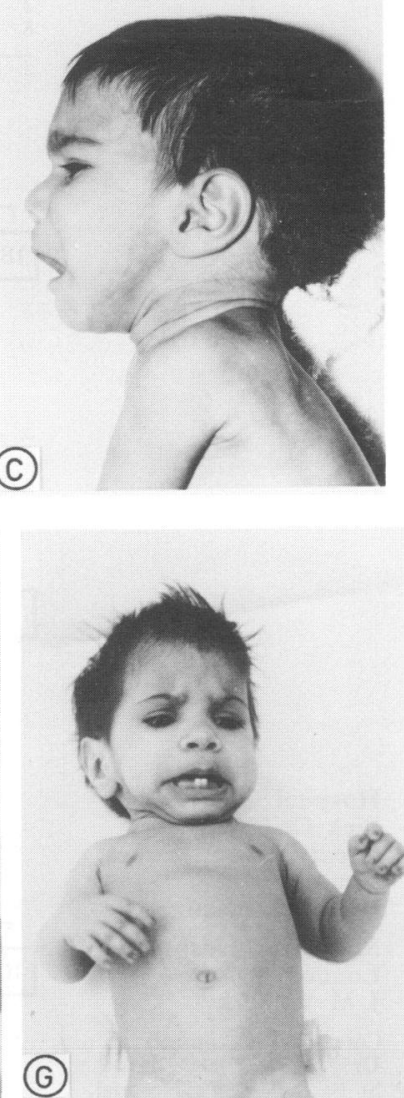

Figure 2 Photographs of affected children. A, B, and C-index case aged 9 months; D, E, F, G-cases 3, 6, 7, and 8 . 
Table 3 Calcium studies

\begin{tabular}{|c|c|c|c|c|}
\hline \multirow{2}{*}{$\begin{array}{l}\text { Case } \\
\text { No }\end{array}$} & \multicolumn{3}{|c|}{ Calcium studies } & \multirow{2}{*}{$\begin{array}{l}\text { Parathyroid } \\
\text { hormone } \\
(\text { ng/l) }\end{array}$} \\
\hline & $\underset{(\text { mmolll })}{\text { Calcium }}$ & $\begin{array}{l}\text { Phosphate } \\
\text { (mmolll) }\end{array}$ & $\begin{array}{l}\text { Alkaline } \\
\text { phosphatase } \\
\text { activity (U/l) }\end{array}$ & \\
\hline $\begin{array}{l}1 \\
2 \\
3 \\
4 \\
5 \\
6 \\
6 \\
7 \\
8\end{array}$ & $\begin{array}{l}1.54 \\
1.25 \\
1.03 \\
1.91 \\
1.65 \\
1.4 \\
1.6 \\
1.53\end{array}$ & $\begin{array}{l}3 \cdot 0 \\
4 \cdot 4 \\
2 \cdot 7 \\
1 \cdot 7 \\
2 \cdot 8 \\
2 \cdot 8 \\
2 \cdot 9 \\
\text { Not measured }\end{array}$ & $\begin{array}{l}640 \\
481 \\
1387 \\
310 \\
156 \\
251 \\
\text { Not measured } \\
276\end{array}$ & $\begin{array}{l}<156 \\
50 \\
<40 \\
>1000 \\
>100 \\
52 \\
\text { Not measured } \\
23\end{array}$ \\
\hline $\begin{array}{l}\text { Reference } \\
\text { ranges }\end{array}$ & $2 \cdot 2-2 \cdot 67$ & $0.83-1.78$ & $100-1000$ & $\begin{array}{l}120-410 \\
\text { (with normal } \\
\text { serum calcium } \\
\text { concentration) }\end{array}$ \\
\hline
\end{tabular}

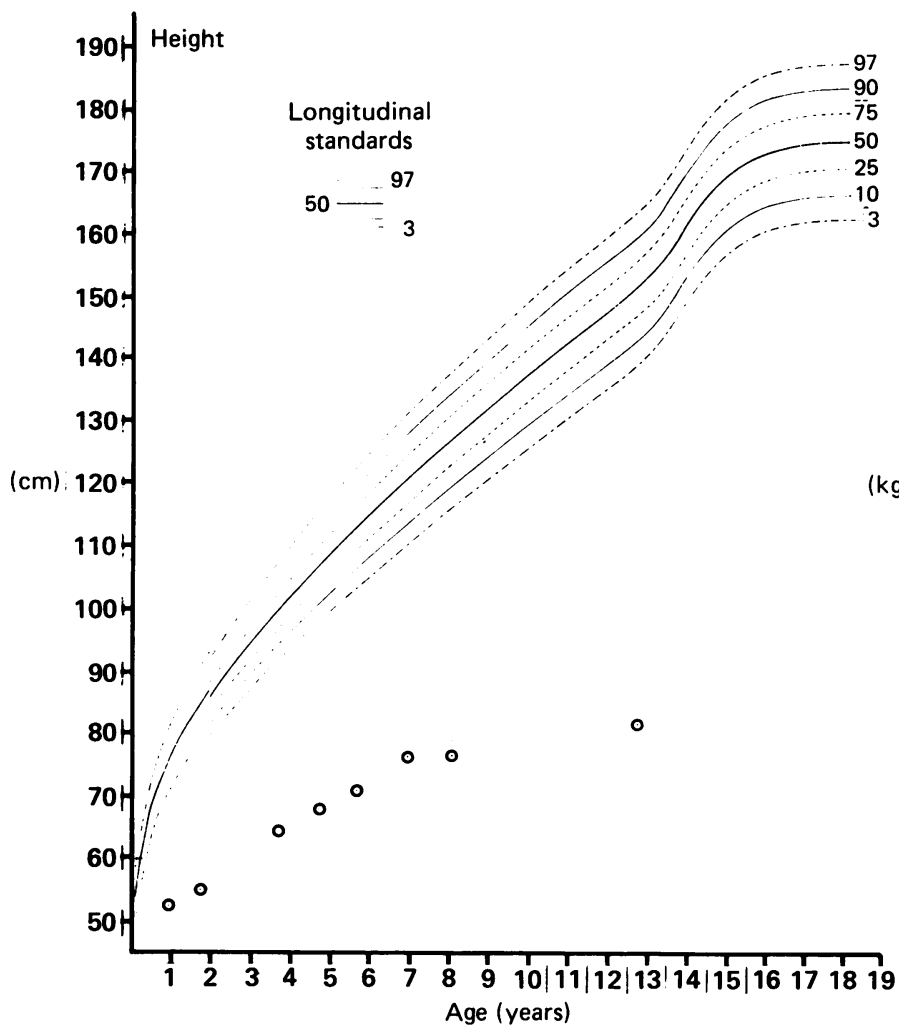

Figure 3 Growth charts of index case.

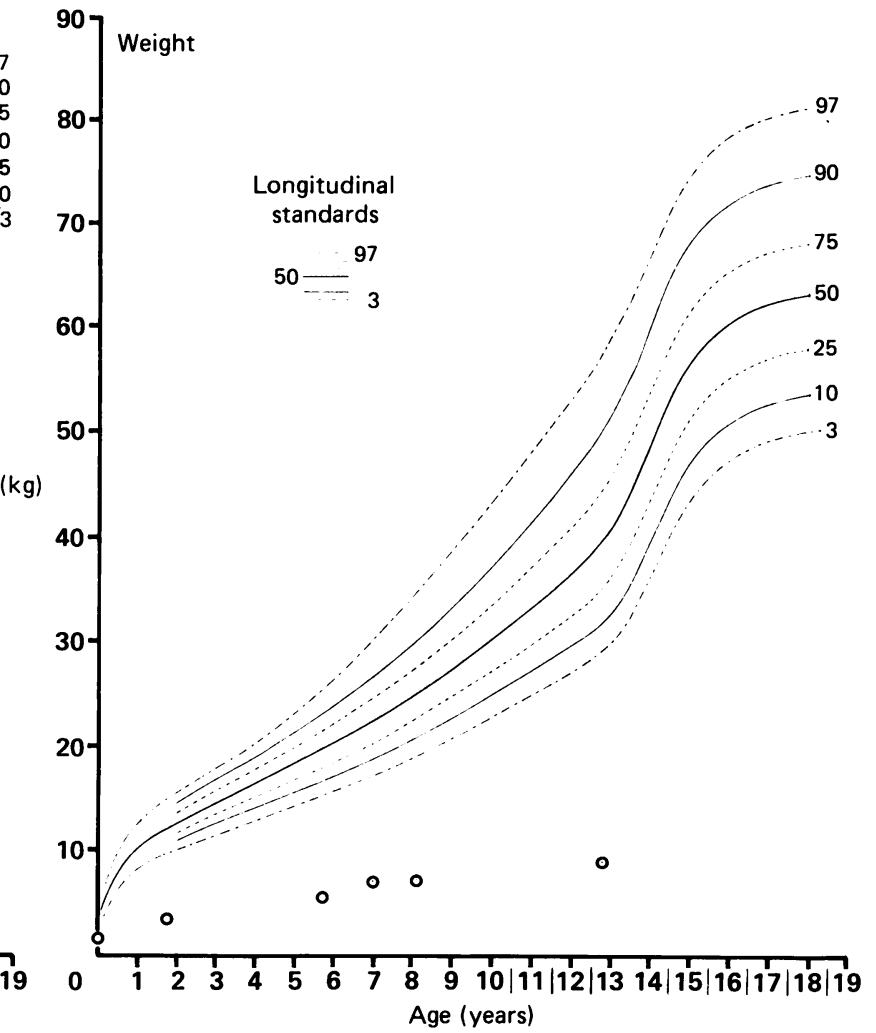

and head circumference of $45 \cdot 0 \mathrm{~cm}$ (table 2). He had clinical evidence of heart failure and an enlarged liver, both of which were thought to be secondary to iron overload from repeated transfusion, as the serum ferritin concentration was grossly raised at $11804 \mu \mathrm{g} / \mathrm{l}$ (reference range 40-300). Although the corrected serum calcium concentration has been maintained within the reference range on up to $80 \mu \mathrm{g}$ of $1 \alpha$-hydroxycholecalciferol/day the renal ultrasound scan shows extensive generalised nephrocalcinosis.

CASES 2-8

Pedigrees (fig 1)

All eight children were the product of seven consanguinous marriages between first cousins of Middle Eastern origin. There was no evidence that any of the families were inter-related. Four of the children were boys, and four girls.
Cases 1 and 2 were brothers, and in four of the remaining six families there had been a further five similarly affected siblings with dysmorphism, hypocalcaemia, and recurrent infections who died in infancy.

\section{Auxological data (table 2)}

The standards of Tanner et al have been used for all the auxological data. ${ }^{1-3}$

The birth weights of the seven patients for whom data are available are all below the 10th centile when adjusted for gestational age, indicating that the onset of the failure to thrive was prenatal. Measurements of height, weight, and head circumference made at the time of the latest assessment have been given, and show that all the variables are $<-2$ SD scores (approximates to third centile) for age and sex. There are no discrepancies among the height, weight, and head circumference SD scores. 
Developmental delay

All the patients were severely developmentally retarded. Motor milestones were especially affected, with only case 1 being able to walk, and none of the other seven children being able to crawl or stand unsupported. Speech was limited to babble in all children except case 1 . Although cardiorespiratory arrest secondary to hypocalcaemia had occurred in two of the children (cases 2 and 3), this could not account for the severe developmental delay in the other six.

Hearing was normal, although case 4 had bilateral perforated tympanic membranes that were colonised with Pseudomonas aeruginosa. Vision was also considered to be normal in all patients, although case 3 had cataracts, presumably secondary to hypocalcaemia.

\section{INVESTIGATIONS}

Hypocalcaemia (see table 3)

All eight patients presented with hypocalcaemia in the neonatal period, as did five affected siblings who died in infancy. Radioimmunoassay of the amino terminal human parathyroid hormone concentrations was carried out in seven of the children, and was inappropriately low for the serum calcium in six, confirming hypoparathyroidism. In the seventh child (case 4) the parathyroid hormone concentration was grossly raised $(>1000 \mathrm{ng} / \mathrm{l})$ on three occasions both with and without treatment, suggesting a biologically inert parathyroid hormone. Treatment with $1 \alpha$-hydroxycholecalciferol in a total daily dose of $0.3-1.2 \mu \mathrm{g} /$ day and calcium supplementation of $8 \cdot 1-10.8 \mathrm{mmol} /$ day have returned calcium concentrations to normal in all patients.

\section{Skeletal survey}

Skeletal surveys of all the patients were reviewed. Medullary stenosis of long bones was noted in seven patients and is most clearly seen in the forearm bones and the metacarpals. Other skeletal abnormalities included a valgus deformity of the femoral neck $(n=2)$ and terminal acro-osteolysis in the distal phalanges $(\mathrm{n}=1)$.

\section{Immune function}

Three of the children (cases 2,3, and 5) presented in the neonatal period with septicaemia and there was evidence that at least three further affected siblings had died in infancy of overwhelming infection.

Immunoglobulin concentrations were normal in three children in whom they were measured, but four children (cases 3, 4, 5, and 8) had reduced numbers of all $T$ lymphocyte subsets. Case 3 was given thymic factor twice weekly in a dose of $1 \mathrm{mg} / \mathrm{kg}$ for two years until immune function had return to normal. Case 4 had abnormal polymorph mobility, in addition, but this was thought to be secondary to nutritional factors.

Other investigations

Glucagon stimulation tests of growth hormone release $(100 \mu \mathrm{g} / \mathrm{kg}$ given intramuscularly) were carried out on three of the patients, with peak serum growth hormone concentrations of $6 \cdot 1$, $7 \cdot 8$, and $8 \cdot 7 \mu \mathrm{g} / \mathrm{l}(12 \cdot 2,15 \cdot 6$, and $17 \cdot 4 \mathrm{mU} / \mathrm{l})$, respectively. Thyroid function was normal in all patients.

Liver function tests were carried out in five children; two have always had normal levels and three had increased transaminase activities. Case 1 has had grossly abnormal liver function tests (reference ranges given in parentheses)bilirubin concentration $35 \mu \mathrm{mol} / 1(<17)$, alanine aminotransferase activity $156 \mathrm{U} / 1$ (6-16), aspartate aminotransferase activity $309 \mathrm{U} / 1$ (6-16), and $\gamma$ glutamyltransferase activity $855 \mathrm{U} / 1$ (10-50)—which were thought to be secondary to iron overload as a result of repeated blood transfusion for thalassaemia major. Case 3 has had a liver biopsy specimen taken, which showed reactive hepatitis but no evidence of chronic liver disease. The abnormal liver function tests in this patient (bilirubin $144 \mu \mathrm{mol} / \mathrm{l}$, alanine aminotransferase $144 \mathrm{U} / 1, \gamma$ glutamyltransferase $900 \mathrm{U} / \mathrm{l}$ ) improved spontaneously with no treatment. Case 5 has had persistent unexplained increase in transaminase activities (alanine aminotransferase $283 \mathrm{U} / 1$ and aspartate aminotransferase $133 \mathrm{U} / \mathrm{l}$ ).

Six of the patients have had chromosome analyses performed, including Giemsa banding, and no abnormality has been found.

\section{Discussion}

The association of extreme failure to thrive, dysmorphic features, developmental delay, abnormal skeletal survey, and hypoparathyroidism has not to our knowledge been previously reported. The similarity of the pattern of anomalies in the eight children described and in five further affected siblings indicates a syndrome that has a common mode of determination. Though this new syndrome does have some features in common with the KennyCaffey syndrome, such as short stature and hypocalcaemia (caused by hypoparathyroidism or an abnormal parathyroid hormone) in association with abnormalities in the skeletal survey, it differs substantially in that our group of patients had no evidence of macrocephaly, and were all developmentally delayed. ${ }^{4-7}$ DiGeorge's syndrome, a defect of the third and fourth branchial arches, may present with hypoparathyroidism and immune dysfunction, although both are commonly transient. ${ }^{8}$ Most patients with DiGeorge's syndrome, however, present with congenital heart disease, and though echocardiography was not carried out on our patients none had any abnormal findings on clinical examination. ${ }^{9}$

As the consanguinuity rate approaches $60 \%$ in some populations within the Middle East, the emergence of an autosomal recessive condition is more likely and this is the presumed mode of inheritance of this syndrome. ${ }^{10-12}$ Larger numbers of patients will have to be identified before its genetics can be more fully elucidated; in the meantime recognition of affected children will 
allow earlier prescription of appropriate treatment.

We thank Professor ME Pembrey, Dr M Baraitser, and Dr E Thompson for assistance with genetics and dysmorphology,
and Dr DG Shaw and Dr D MacVicar for radiological advice. and Dr DG Shaw and Dr D MacVicar for radiological advice. Dr AP Mowat, Dr MCJ Hunt, Dr DB Grant and Professor CGD Brook have given permission for us to report their patients. Professor PJ Graham, Professor CGD Brook, and Professor JK
Lloyd gave invaluable advice in the preparation of the manuscript.

1 Tanner JM, Whitehouse RH. Clinical longitudinal standards for height, weight, height velocity and weight velocity and
the stages of puberty. Arch Dis Child 1976;51:170-9.

the stages of puberty. Arch Dis Child 1976;51:170-9.
2 Tanner JM, Whitehouse RH, Takaishi M. Standards from birth to maturity for height, weight, height velocity and weight velocity; British children 1965. Arch Dis Child 1966; 41:454-71.

3 Tanner JM, Thompson AM. Standards for birthweight as gestational periods from 32 to 42 weeks, allowing for maternal height and weight. Arch Dis Child 1970;45:566-9.
4 Kenny FM, Linarelli $L$. Dwarfism and cortical thickening of tubular bones. Am $f$ Dis Child 1966;111:201-7.

5 Caffey J. Congenital stenosis of medullary spaces in tubular bones and calvaria in two proportionate dwarfs- mother and son-coupled with transitory hypocalcemic tetany. $A \mathcal{J} R$ son- coupled with

6 Lee WK, Vargas A, Barnes J, Root AW. The Kenny-Caffey syndrome; growth retardation and hypocalcaemia in a young boy. Am $\mathcal{F}$ Med Genet 1983;14:773-82.

7 Fanconi S, Fischer JA, Wieland P, et al. Kenny syndrome; evidence for idiopathic hypoparathyroidism in two patients and for abnormal parathyroid hormone in one. $\mathcal{F}$ Pediat 1986;109:469-75.

8 Di George AM. Discussion. In: Cooper MD, Peterson RDA Good RA. A new concept of the cellular basis of immunity. 7 Pediatr 1965;67:907-8.

9 Conley ME, Beckwith JB, Mancer JFK, Tenckhoff L. The spectrum of the Di George syndrome. 7 Pediat 1979;94: s83-90.

10 Habib Z, Book JA. Consanguinity and incidence of thalas-

saemia in Egypt. Hereditas 1983;99:215-7. Hafez M, el-Tahan H, Awadalla M, el-Khayat H, Abdel-
Gafar A, Ghoneim M. Consanguinous matings in the Egyptian population. 7 Med Genet 1983;20:58-60

12 al-Awadi SA, Naguib KK, Moussa MA, Farag TI, Teebi AS, el-Khalifa MY. The effect of consanguinous marriages on reproductive wastage. Clin Genet 1986;29:384-8.

\section{British Paediatric Association Annual Meetings}

University of Warwick:

16-19 April 1991

7-10 April 1992

20-23 April 1993

12-15 April 1994 